\title{
Design and Analysis Based on US Telephone Service Selection Model
}

\author{
Wei Chen ${ }^{*}$ and Bo Ma \\ Southwest national university of Chengdu, China \\ ${ }^{*}$ Corresponding author
}

\begin{abstract}
In today's society, with the development of cell phones, it has brought more and more convenience to us. More and more people use cell phones and landline phones to assume the trend of being replaced. While using cell phones, energy consumption has risen dramatically. In order to save energy so as to achieve social sustainability, developing countries that facilitate less-than-optimal telephone service can analyze the energy consumption of landline phones and cell phones to help solve their energy consumption problems and choose different telephone services. This article will use MATLAB as a supporting tool to design and analyze telephone services in the U.S.
\end{abstract}

Keywords-phone service; energy consumption; landline phones; cell phones

\section{INTRODUCTION}

The U.S is the world's top country in terms of economy and science and technology. By analyzing the telephone service choices in the country, we can well obtain the energy consumption data generated by different telephone services. The data is then provided to developing countries that do not have sound telephone service. Based on these data, we can select the telephone service with low energy consumption and convenient use according to the national conditions so that the investment weight on the communication facilities can be rationally distributed. This is a great reference for saving energy and choosing telephone services. This article uses MATLAB to analyze telephone services in the U.S and to establish a mathematical model of the use of telephone services in the U.S. Based on this model, a universal telephone service is designed.

\section{Phone Transition Model}

Telephone services are gradually being transitioned from landline phones to handsets. In order to calculate the energy consumption of both, used to compare which phone service is better. This article devised a model to describe the relative changes in the number of users of cell phones and landline phones [1].
TABLE I. CELL PHONE AND LANDLINE POWER CONSUMPTION AND LIFE EXPECTANCY

\begin{tabular}{cccc}
\hline & $\begin{array}{c}\text { Power } \\
\text { consumption/kWh }\end{array}$ & life/a & $\begin{array}{c}\text { The } \\
\text { probability of } \\
\text { use/y }\end{array}$ \\
\hline $\begin{array}{c}\text { Cell phone } \\
\begin{array}{c}\text { Cordless } \\
\text { phone } \\
\text { Landline } \\
\text { phone }\end{array}\end{array}$ & 5.613 & 1.5 & $\mathrm{x}$ \\
\hline
\end{tabular}

The model calculates the total energy consumed by U.S. public telephones during 2008-2015. Using a simple equation, calculate the curve integral over the period of 2008, which is the lower limit and 2015 is the upper limit. The result of the points shows that the average number of people who own cell phones each year is a multiple of time. Cell phone average annual power consumption is $5.613 \mathrm{~kW} \cdot h$, and the average annual landline phone energy consumption is :

$$
\begin{gathered}
28 \mathrm{~kW} \cdot h \times 0.667+2.2 \mathrm{~kW} \cdot \mathrm{h} \times 0.333=19.4 \mathrm{~kW} \cdot \mathrm{h} \\
E_{\text {phone }}=(\text { AveragePopulation }) \times\left[\int_{2008}^{2015} \text { Equation } \times\left(\frac{\text { PhoneEnergyUsed }}{\text { Year }}\right)\right]
\end{gathered}
$$

If every American has a cellphone without a landline, the total energy consumed is about $13 \times 10^{8} \mathrm{~kW} \cdot \mathrm{h}[2-4]$.

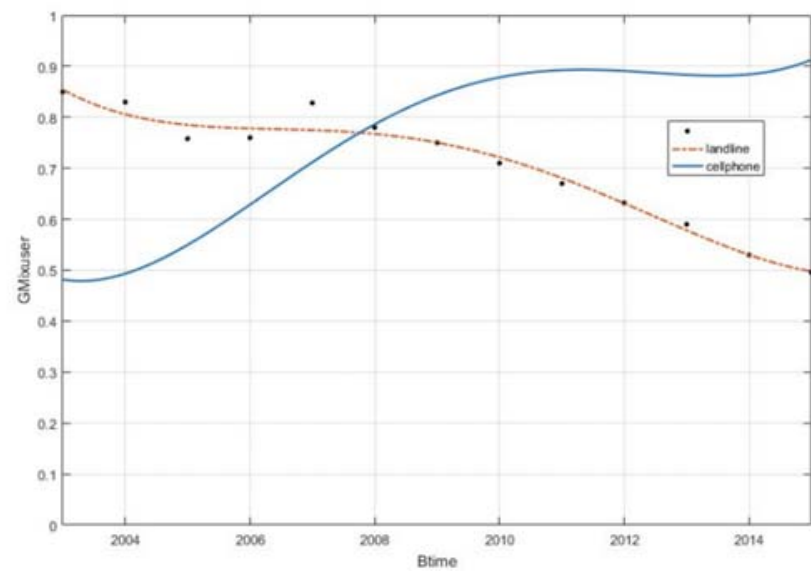

FIGURE I. LANDLINEPHONE AND CELLPHONE TRANSITION TRENDS

In the real world, landline phone usage does not drop to zero. But to maintain a fixed ratio, that is, the current trend of change with resistance to change.If cell phone does not work 
properly for some reason or some people feel that the landline phone is safer and more comfortable, U.S citizens will have a significant percentage of them opting to keep the landline as long as the phone is still available. While considering the above factors, a second model to consider changes in resistance is established, as shown in Figure 1. According to the data drawn by the landline phones and cell phones in recent years, the landline phones can not be completely replaced by cell phones in practice, but dropped to a certain percentage.

Use formula (2) to calculate the energy consumption of mobile phones and landline phones respectively:

$$
\begin{gathered}
E_{\text {cell }}=289933500 \times\left[\int_{2008}^{2015} \text { CellEquation } \times\left(\frac{5.613 \mathrm{~kW} \cdot \mathrm{h}}{\text { Year }}\right)\right]=15.36 \times 10^{8} \mathrm{~kW} \cdot \mathrm{h} \\
E_{\text {landlinghore }}=289933500 \times\left[\int_{2008}^{2015} \text { LandlineEquation } \times\left(\frac{19.4 \mathrm{~kW} \cdot \mathrm{h}}{\text { Year }}\right)\right]=17.9 \times 10^{8} \mathrm{~kW} \cdot \mathrm{h} \\
E_{\text {tot }}(\text { M o del })=E_{\text {cell }}+E_{\text {land linephone }}=33.26 \times 10^{8} \mathrm{~kW} \cdot \mathrm{h}
\end{gathered}
$$

TABLE II. ENERGY CONSUMPTION UNDER BOTH MODELS

\begin{tabular}{cccc}
\hline $\begin{array}{c}\text { Transition } \\
\text { mode }\end{array}$ & $\begin{array}{c}\text { Cell } \\
/\left(10^{9}\right) \mathrm{kWh}\end{array}$ & $\begin{array}{c}\text { Landline } /\left(10^{9}\right) \\
\mathrm{kWh}\end{array}$ & $\begin{array}{c}\text { Total } \\
\text { energy } /\left(10^{9}\right) \mathrm{kWh}\end{array}$ \\
\hline Immediately & 13 & 0 & 13 \\
Model & 15.36 & 17.9 & 33.26 \\
\hline
\end{tabular}

By comparison, the energy consumption of both phones running at the same time is far greater than the energy consumption of only the phone is running. As can be seen, the longer the landline phone rollout takes, the more energy the United States will waste.

\section{NATIONAL TELEPHONY SELECTION MODEL}

Now suppose a country has a population of about 300 million and has the same economic status as the current U.S. But there is no way of communication. Choose the best phone service for this country. There are several families in a country. The family as the basic unit of the model. And then from the family's energy consumption to predict the country's energy consumption [5].

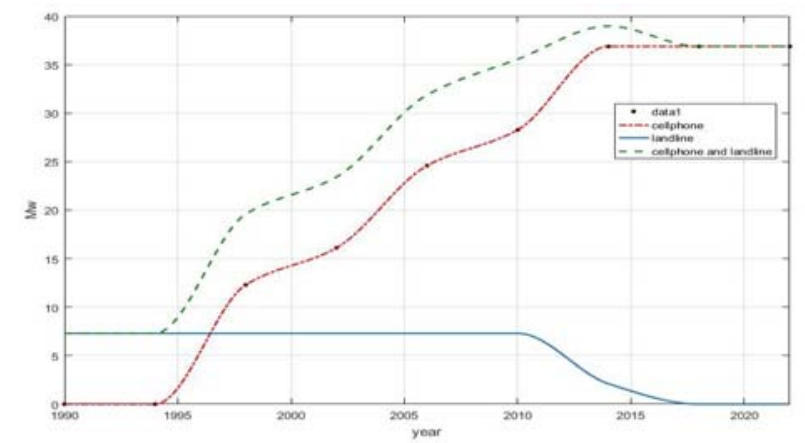

FIGURE II. ENERGY CONSUMPTION MODEL OF THE STAGES OF THE FIGURE

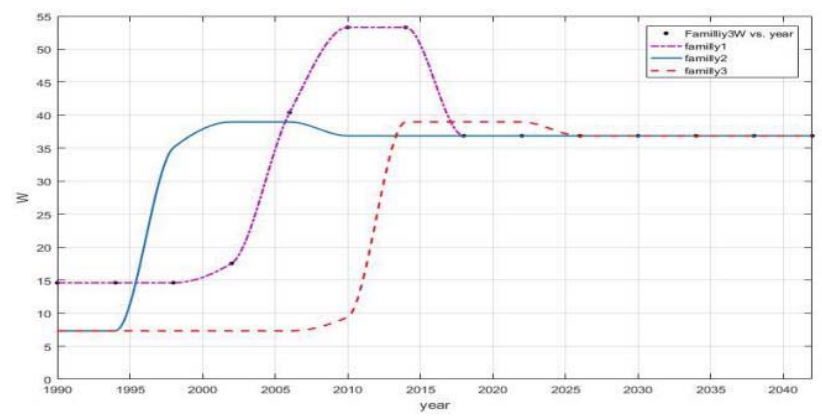

FIGURE III. ENERGY CONSUMPTION MODEL DIAGRAM FOR ONLY 3 HOUSEHOLDS

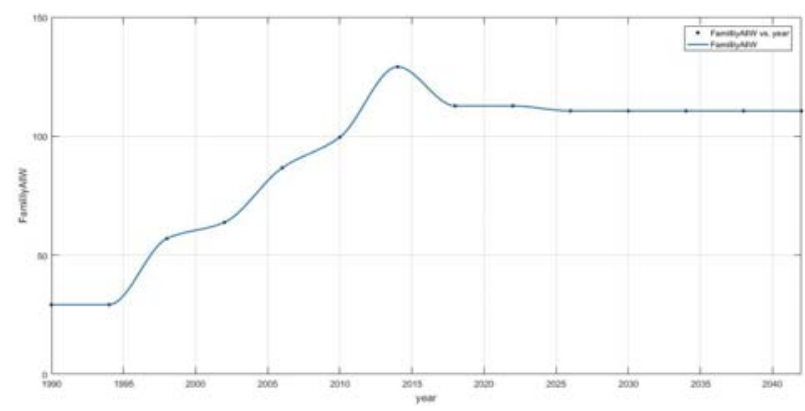

FIGURE IV. ESTIMATED ENERGY CONSUMPTION MODEL PSEUDO-COUNTRIES

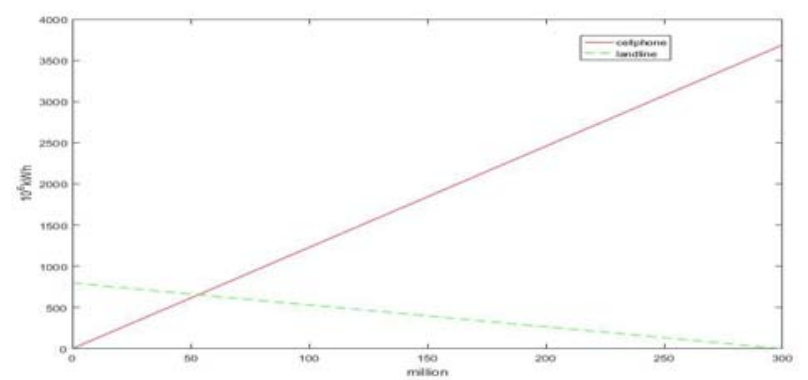

FIGURE V. COMMUNICATION ENERGY CONSUMPTION DIAGRAM

\section{(1) Family}

Each family has the following characteristic parameters:

M: Number of family members using cell phone.

t: The number of landline phones.

C: The number of cell phones.

The case of each family can use the above parameters to represent. Suppose a family can only be one of four following periods at a time. Each period has two related conditions $t$ and c:

Initial period --only use landline : $\mathbf{t}>\mathbf{0 ,}, \mathbf{c}=\mathbf{0}$.

Mixed period --There is a landline phone at the same time the first phone : $\mathbf{t}>\mathbf{0 , 0}<\mathbf{c}<\mathbf{m}$.

Transition --Each person has a cell phone but the landline is retained: $\mathbf{t}>\mathbf{0}, \mathbf{c}=\mathbf{m}$.

The final period--Everyone uses a cell phone instead of a landline: $\mathbf{t}=\mathbf{0}, \mathbf{c}=\mathbf{m}$. 
Assuming these four periods are unrelated. Every family does not have to go through every period. As long as a family enters into a period, it will not go through the period it has previously experienced[6-8]. Suppose there are 3 people in a family $(\mathrm{m}=3), 1$ landline $(\mathrm{t}=1)$, and no cell phone $(\mathrm{m}=0)$. Figure 2 shows the energy consumption of a family over the four periods.

In Figure 2, the landline curve shows the energy consumption of the landline phone in four stages. The landline phone power consumption is a steady value when family members do not all buy a cell phone, and they no longer use landline until they own a cell phone. Finally, the fixed telephone is canceled, the energy consumption of the fixed telephone slowly decays to zero. The cellphone curve represents the energy consumption of cell phones. The three inflection points in the process of change represent the energy consumption of three people in the family after they bought the cell phone respectively. When all three people buy the cell phone, the energy consumption of a cell phone of the family maintains a stable value. The cellphone and landline curve represents the total energy consumption of a landline phone and a cellphone, which is the sum of the other two curves. The power consumption is only generated by the cellphone after canceling the landline phone call.

\section{(2) Country}

Through the integration of various types of family situations, the energy consumption in the transition of the entire country from the use of landline phones to handsets is simulated. Assuming only one country has only 3 families, the energy consumption in this country is shown in Figure $3[9-10]$.

In the model, 3 families in this country are randomly selected and monitored for energy consumption by communication method, and each of these 3 families has 3 members. Therefore, the energy consumption of the 3 families eventually reaches a common value after all choose to use the cell phone. The energy consumption of each family will be collected daily to obtain a total, which can be the national energy consumption as shown in figure 4 . In order to use the relevant data in the model, the following values are calculated:

$C_{\text {wattage }}:$ The average energy consumption of a cell phone over its useful life.

$L_{\text {wattage }}$ : The average energy consumption of a landline over its lifetime.

Calculated as follows:

$$
\begin{aligned}
& C_{\text {wattage }}=C h \text { arger } r_{\text {wattage }}+\left[\frac{C_{\text {upfront }}(\text { joules })}{C_{\text {lifetime }}(\sec \text { onds })}\right]=4.182 \mathrm{~W} \\
& L_{\text {wattage }}=\text { Cordless } \text { wattage }+\left[\frac{L_{\text {upfront }}(\text { joules })}{L_{\text {lifetime }}(\sec \text { onds })}\right]=5.304 \mathrm{~W}
\end{aligned}
$$

The type of telephone service that is tested for the following three pre-determined scenarios to determine which approach to introduce is more favorable for the country's energy consumption and economy: (1) cell phone only; (2) landline phone only; (3) cell phone and landline phone two ways to mix. In Figure 5, the horizontal axis represents the number of people using the mobile phone, the vertical axis represents the energy consumed, the cellphone curve shows the case of using the mobile phone, and the landline curve shows the case of using the fixed phone.

(1)Only use cell phones: Assuming 300 million people use cell phones, the total energy consumption per cell phone multiplied by the number of cell phones is about $3.7 \times 10^{9} \mathrm{~kW} \cdot \mathrm{h}$.

(2)Only use landline: Assuming 300 million people are in households and 3 in each family, 100 million households use landline phones, and the total energy consumption is about $0.8 \times 10^{9} \mathrm{~kW} \cdot h$.

(3)Mixed use of mobile phones and landline phones: The intersection point of the two lines is the lowest point of energy consumption, that is, the minimum total energy consumption is $0.655 \times 10^{9} \mathrm{~kW} \cdot \mathrm{h}$ when the number of mobile phones is $53.2879 \times 10^{6}$

According to the energy consumption and overall economic factors, the best way to call in this country is to select the phone service that is a combination of cell phones and landline phones.

\section{CONCLUSION}

Cell phones have many uses of landline phones and social impact, and landline phones more than the reliability and stability. From the perspective of energy consumption, landline phone energy consumption should be lower than cell phones, the use of landline phones will help save energy and achieve social sustainability. From an economic point of view, cell phones have taken over the market, landline phones will gradually be eliminated. In our country, landline phones have very few holdings and cell phones have become the mainstream choice for telephone services. To reduce the energy consumption of telephone services and achieve sustainable development, governments and investors should be inclined to increase the funding weights for developing energy-saving cell phones .

\section{References}

[1] Temam R, Miranville A, Gremaud P. Mathematical modeling in continuum mechanics /[M]. Cambridge University Press, 2001.

[2] S. Ahmad Hajimolana, M. Azlan Hussain, W.M. Ashri Wan Daud, et al. Mathematical modeling of solid oxide fuel cells: A review[J]. Renewable and Sustainable Energy Reviews, 2011, 15(4):1893-1917.

[3] Pandiarajan N, Muthu R. Mathematical modeling of photovoltaic module with Simulink[C]// International Conference on Electrical Energy Systems. IEEE, 2011:258-263.

[4] Cheong R, Hoffmann A, Levchenko A. Understanding NF- $\kappa$ B signaling via mathematical modeling[J]. Molecular Systems Biology, 2014, 4(1):-.

[5] Dutil Y, Rousse D R, Salah N B, et al. A review on phase-change materials: Mathematical modeling and simulations[J]. Renewable \& Sustainable Energy Reviews, 2011, 15(1):112-130.

[6] Tung K K. Topics in mathematical modeling[J]. Princeton University Press, 2016.

[7] Temam R, Miranville A, Gremaud P. Mathematical modeling in continuum mechanics /[M]. Cambridge University Press, 2001.

[8] Radwan A G, Fouda M E. On the Mathematical Modeling of Memristor, 
Memcapacitor, and Meminductor[M]. Springer International Publishing, 2015.

[9] Politzer P, Murray J S, Clark T. Mathematical modeling and physical reality in noncovalent interactions.[J]. Journal of Molecular Modeling, 2015, 21(3):52.

[10] Kolpak E P, Ivanov S E. Mathematical modeling of the system of drilling $\operatorname{rig}[\mathrm{J}]$. Contemporary Engineering Sciences, 2015, 8(13):699-708. 